\title{
An Overview of Women Entrepreneurship from Islamic Perspective
}

\author{
Said Muhammad ${ }^{a}$, Kong Ximei ${ }^{b}$, Ilyas Sharif ${ }^{c}$, Zahoor ul Haq ${ }^{\text {d }}$ \\ ${ }^{a}$ Ph.D Scholar, School of Business, Zhengzhou University, P.R. China \\ Email: said100487@gmail.com \\ ${ }^{\mathrm{b}}$ Associate Professor, School of Business, Zhengzhou University, P.R. China \\ Email: kongximei@126.com \\ ${ }^{\mathrm{c}}$ Lecturer Quaid-e-Azam College of Commerce, University of Peshawar, Pakistan \\ Email: ilyasqacc@uop.edu.pk \\ ${ }^{\mathrm{d}}$ Associate Professor, Government College of Management Sciences Mardan II, Pakistan \\ Email: zahoorulhaq177@gmail.com
}

\begin{tabular}{l}
\hline ARTICLE DETAILS \\
\hline History: \\
Accepted 10 Dec 2020 \\
Available Online 31 Dec 2020 \\
\hline Keywords: \\
Women Entrepreneurship, \\
Women Empowerment, Push and \\
Pull Factors, Socio-Economic \\
Development, Poverty, \\
Motivation, Work-Life Balance, \\
Financial Independence
\end{tabular}

JEL Classification:

M54, O24, D71

DOI: $10.47067 /$ reads.v6i4.285

\begin{abstract}
Islam has encouraged women to participate in entrepreneurial activities for economic prosperity and social growth. Nevertheless, their participation in economic activities is very lesser than men globally. Previously, the field of entrepreneurship has been regarded as a male dominant sector. Entrepreneurship flourishes due to economic, social, ethical, and environmental factors while the practice of Sharia principles works as a catalyst in this process. Women entrepreneurship helps in alleviating poverty and unemployment that leads to socio-economic prosperity in a country. The motivation of starting women businesses varies in different cultures and geographic regions. Women engagements in different business activities can not only empower them socially and financially but can also share the household economic burden with men. Furthermore, it will also help them to make their decisions independently. Their entrepreneurial income can be used for their children's education, health, and the betterment of society. They can also use the option of partnership within the family for the financial and social network. The challenges faced by these women entrepreneurs can be handled with their family support. This review provides a general overview of concepts, motives, challenges, and the prospects of women entrepreneurship from an Islamic perspective.
\end{abstract}

(C) 2020 The authors. Published by SPCRD Global Publishing. This is an open access article under the Creative Commons AttributionNonCommercial 4.0

Corresponding author's email address: said100487@gmail.com

\section{Introduction}

Half of the world population consists of women (Khalid et al., 2020) but, their economic participation is very low as compared to men. Man and woman are like two wheels of a vehicle of society where both play a critical and undeniable role in every walk of life. If both take part in business 


\section{Review of Economics and Development Studies, Vol. 6 (4) 2020, 857 - 866}

activities then economic prosperity will sustain in society. Statutorily, women may start any legal economic activity for earning their livelihood. In recent decades, women's business has globally got the attention of researchers as an emerging field (Henry et al., 2016; Jamali, 2009; Jennings \& Brush, 2013). That's why it has been considered an active ingredient for development in the leading nations of the world. It not only creates jobs but also stimulates the economic growth of the country (Vladasel et al., 2020). It is a crucial element for reducing the extreme poverty of the masses (Jones Christensen et al., 2015; Kimbu \& Ngoasong, 2016; Nasir et al., 2019; Sutter et al., 2019).

Religion has been considered as an actor to influence entrepreneurial activities. It teaches, allows, and promotes the cultural values system in the community (Ribeiro et al., 2012). Within different religious and cultural contexts, entrepreneurial culture varies among people. One of the studies (Kantor, 2005) narrated that Muslim women entrepreneurs showed greater equality than Hindu women to control their income. This may be due to less dependence of men on women's income due to patriarchal norms. Islamic economic system promotes entrepreneurial activities, social well-being, and economic justice (Shinkafi Akilu \& Ali Nor, 2018). History is full of shreds of evidence that women can do business as per the teachings of Islam. In the Holy Quran Allah SAW, says that "Trade has been permitted and interest has been forbidden" (Quran 2:275). Moreover, one of the well-known examples of Muslim businesswomen is Hazrat Khadeeja (r.a), the $1^{\text {st }}$ wife of the Prophet Muhammad (Peace Be Upon Him) who recognized herself as a successful trader of her time which shows there is nothing wrong if women get involved in entrepreneurial activities. Islam has issued some guidelines for their daily economic engagements.

Women are underutilized in the majority of Muslim countries due to low literacy and poverty (Anggadwita et al., 2015). Muslim women are supposed to follow the Holy Quran and the sayings of the beloved Prophet (PBUH) in their business activities. Doing business in this way is considered as worship and raises their spirituality. These guidelines remind the masses to believe and act within the circle of Sharia (Shinkafi Akilu \& Ali Nor, 2018). Women can engage themselves in businesses like manufacturing, trade, services, and other commercial activities permitted by the Sharia and restrict themselves from interest-based activities, smuggling, dancing, pork breeding, wine business, and gambling. Women entrepreneurship can take any modalities like Musharikah, Mudarabah, Ijarah, etc. permitted by Sharia. They may easily start different small-scale businesses at their homes or such business centers where only females can come for shopping. Moreover, in today modern technological and digitalization era, they can take part in online business activities as well. Online business activities are easier and more doable than installing machinery, renting space, however it depends on education and access to technology and services.

\section{Motives of Women Entrepreneurs}

Female entrepreneurs may have different motives and goals for starting a business (Anggadwita et al., 2015). One of the goals in literature is to improve control over the entrepreneurial income. Furthermore, a large body of evidence (Benería \& Roldan, 1987; Mencher \& World, 1988; Schultz, 1993) showed that the women controlled income has been spent more on family than men's controlled income. Some needs for starting entrepreneurship may be the same for women but the basic needs may be different due to religious belief. Furthermore, a study (Hashmi, 2018) showed that high-income countries don't promote a high rate of entrepreneurship and it was realized that low-income countries have good prospects for women entrepreneurship. Different studies recognized that lack of resources is the primary cause of poverty (Field et al., 2013; Fischer, 2013). The motivational factors can be divided into push and pull factors. Push factors are related to necessities, guided by the external factors that are more important for women than men. (Aidis et al., 2007) reported unemployment and economic 
reasons as a push factor. Gender inequality has been referred by the authors as a push factor in the developed and underdeveloped world (Aidis et al., 2007; Baughn et al., 2006). Due to restriction and discrimination of women to participate in the formal labor force, self-employment is considered as a survival strategy and can easily be managed with work-life balance (Baughn et al., 2006). Pull factors motivate women entrepreneurs to attain status in society. It includes opportunities for independence, success, and satisfaction derived from entrepreneurship. The researchers explored many entrepreneurial motives over the years and classified them into a necessity and opportunities-driven motives (Hilson et al., 2018). In light of the literature, these motivational factors of women entrepreneurs have been grouped into push and pull factors as shown in Fig.1. (Aparicio et al., 2016; Block \& Wagner, 2010; Eijdenberg et al., 2015; Fairlie, 2013; González-Pernía et al., 2018; McMullen et al., 2008; Parker, 2018; Rey-Martí et al., 2015; Sadeghi et al., 2019; C. C. Williams, 2008; N. Williams \& Williams, 2014).

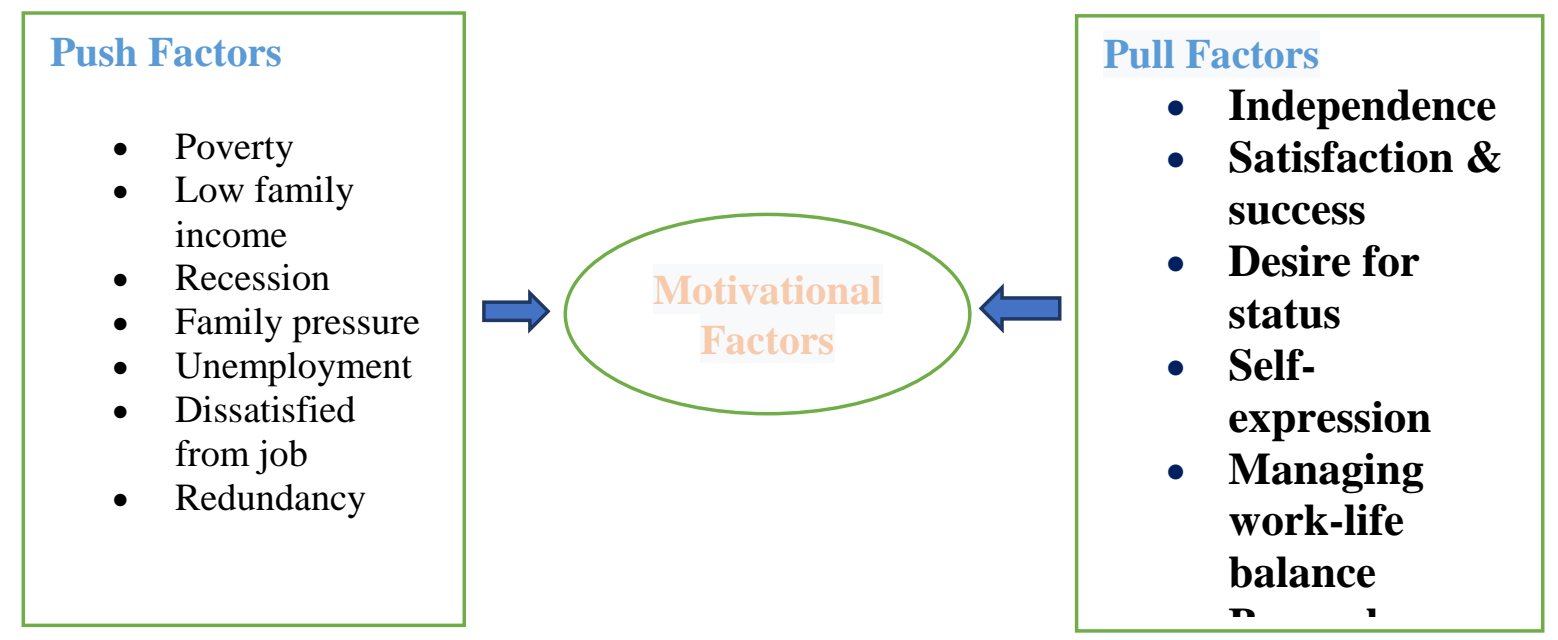

Fig.1. Motivational Factors of Women Entrepreneurs

\section{The Bright Side of Women Entrepreneurship}

Females can independently work for their business. By nature, women are punctual and hardworking. Women have the talent and potential, but it is considered as untapped in many countries (D. Kelley et al., 2011; Marlow et al., 2012). They can easily adapt themselves according to the situation. They can effectively balance the domestic and business affairs and can ensure the active utilization of their time. Women entrepreneurs can add value to societies in different ways. As self-employ, it becomes a source of income for their children and family members. It has the strength to create employment, promote economic growth, and social welfare (Özsungur, 2019).

\subsection{Domestic Merits}

Women can support their families (Leung et al., 2020) by successfully running their businesses. They can successfully run their businesses and domestic activities simultaneously (Jensen et al., 2017; Sun et al., 2020). They can engage other family members if they are free and don't have work. Women entrepreneurs do not become a financial burden for their families and society rather, they become a player in financial matters. With the help of financial independence, they can effectively meet their domestic needs and attains financial freedom. They can easily afford the cost of quality education for their kids and can give a helping hand to their parents, husband, and other family members to support them financially. 
Review of Economics and Development Studies, Vol. 6 (4) 2020, 857 - 866

\subsection{Economic Merits}

Islam gives freedom to women to be engaged in economic activities. Due to inflation and epidemic outbreak Covid-19, men cannot exclusively meet the financial needs of their households that compelled them to search for additional sources of revenue (Oukil, 2013). If Businesswomen can earn more profit as their customers (females) naturally like more shopping. Many researcher claims at the economic level that women engagements in entrepreneurial activities have a contribution to GDP growth and economic development (Zeb \& Ihsan, 2020). Women entrepreneurship is a very emerging sector, running and operational cost of women businesses is usually very low due to small scale business but can enhance the financial position of their family.

\subsection{Societal Merits}

Societies grow when there is financial independence. Islam gives equal rights to men and women to actively run their own business within boundaries for the shared prosperity of the society (Oukil, 2013). There is no place for gender discrimination in Islam which cannot be a hurdle for women entrepreneurship. In areas where society does not like jobs of females, then women may start their home-based businesses where they would not require either to go out of their homes or interact with male members. Pashtun society in most of the cases does not allow women to visit the market for shopping, then home-based women businesses provide them opportunities for shopping at their convenience and choice. The entrepreneurial opportunity will empower marginalized women and on the other hand from the reform perspective it leads to reduce poverty by identifying opportunities for social change (Calton et al., 2013; De Clercq \& Honig, 2011; Mair et al., 2016). The institutional and social changes are dynamic and cannot be predicted due to uncertainty. Such women can financially support their families and help in solving financial problems at the micro and macro level in an economy. Many domestic, social, economic, problems will resolve if females take an active part in running and managing their own business.

\section{Multifaceted Challenges Faced by Muslim Entrepreneurs}

The challenges faced by women entrepreneurs differ around the globe. Some classified it into three groups the individual, institutional and socio-cultural factors (Shmailan, 2014), While other categorized these constraints in the form of personal, family and environmental factors. In some cases, women hesitate to play their roles due to socio-cultural norms (Roomi et al., 2018). These ventures are smaller, slower growth, and have less profit potential than their male counterparts (Greene et al., 2003). The performance and growth of their economic activities are also affected by family support, family and household responsibility, and societal expectations role. These challenges have been highlighted in the following three major points, social and cultural, religious, and financial challenges.

\subsection{Social and Cultural Factors}

Keeping the work-life balance is one of the greatest tasks for the majority of businesswomen around the globe. It is a very challenging task for female entrepreneurs to run and manage such businesses in a male-dominant society (Anna et al., 2000). The societal attitude does not support working women and sometimes has a chance of a lack of access to a social network. They run their businesses in such places and ways, where they have no interaction, with males outside their close relatives. Women entrepreneurship is influenced by the patriarchal culture where they perform family responsibilities. External social factors also lead to inequalities and discrimination (De Vita et al., 2014; Rosa \& Dawson, 2006). They have been considered as housewives to perform the primary responsibilities of the household work inside Pakistan. Societal and cultural discrimination influences women's choices and career progress throughout their lives. 
Review of Economics and Development Studies, Vol. 6 (4) 2020, 857 - 866

\subsection{Religious Factors}

In a religious society where people follow religious instructions, religion cannot be separated into individual and economic life. Women businesses will thrive only if they run their business within religious boundaries (Oukil, 2013). Islam is a religion of peace and harmony when women can enjoy every aspect of life within the permissible circle. Islam permits such women businesses where they exclusively serve, deal, and interact with females of the society. Islamic teachings do not allow women to run such businesses where products of the business are prohibited in Islam. Similarly, they cannot interact with men outside their families and our society thinks bad about women who earn money in a mixed-gender environment (Zeb \& Ihsan, 2020). Islam does not allow women to go out of their homes and participate in mixed-gender programs (Kantor, 2005).

\subsection{Financial Factors}

Islamic economics have their sources of financing which is different from the conventional financial system (Salman \& Nawaz, 2018). Women entrepreneurs are using lower debts and have low access to capital than their male counterparts (Chinomona \& Maziriri, 2015; Roomi \& Parrott, 2008). They have controlled access to formal credit financing (Shaw et al., 2001). It needs to utilize their savings and requires overall family support (Cosh et al., 2000). They take a start with a small capital due to complicated formalities and lack of access to financial support. These ventures need financial support and micro-credit loans from financial institutions (Jamali, 2009). The financial support from conventional formal institutions often charges high interest which is considered null and void in Islam. The required loans are treated as Qard e Hasana in the Islamic financial system. Qard e Hasana is an agreement where the borrower will pay only the principal amount to the lender or financial institutions (Zafar \& Sulaiman, 2020). There will be no gain in the form of interest while financing these ventures. Interest is the main challenge while financing their activities from financial institutions.

The other challenges being faced by women entrepreneurs include registration of these ventures, lack of government support, political instability, complicated business start-up, lack of kids care facility (Jahanshahi et al., 2010). Lack of entrepreneurial knowledge and experience is also a major issue for expansion and makes the activities less attractive (Carter et al., 2001; Watson \& Robinson, 2003).

\section{Demerits of Women Entrepreneurship}

Women entrepreneurs may avoid Islamic teachings in their businesses as there is no regulatory body for regulating their entrepreneurial activities. Due to providing the goods at the doorstep or local area, they often charge more amount than the market especially the goods which have no fixed price. Businesswomen spend most of their time in their entrepreneurial activities and cannot spare enough time for their family life and upbringing of their kids (Jamali, 2009; Oukil, 2013). The findings of a study (Kim \& Ling, 2001) showed work-family conflict arises due to factors of work and family domain. Furthermore, the case becomes severe for married women. They have to play the role of a daughter, wife, and mother. The time devoted to one role becomes a hurdle to perform another role. This could be possible with family support otherwise the matter sometimes leads to conflict (Lee Siew Kim \& Seow Ling, 2001). These women find it difficult to attend social events due to their business activities. These businesses promote extravagance among females, as they buy things in bulk for their personal use regardless of the level of their needs and income. These businesses are normally run on a small scale and promote regional development (Baumgartner et al., 2013) but from the tax point of view, they avoid tax due to non-registration with the tax authorities. 


\section{Prospects of Women Entrepreneurship}

We are living in a male-dominant society having power control inside the family and women is socially and financially dependent on men (Zeb \& Ihsan, 2020). To reduce the dependency on men, new trends have been set and women are trying their best to engage themselves in economic activities and can successfully run many ventures. Global Entrepreneurship Monitor (D. J. Kelley et al., 2017) reported that women are heeding in the business world and an estimated 163 million individuals in 2016 have started or running new ventures in 74 states. Women engaged and support their families in different fields of life facing a lot of challenges (Nasir et al., 2019). By balancing these challenges with their personal and family life they could not focus on their health. Some of the sectors in which women entrepreneurs are engaged, require more effort, and traveling outside the home to perform those tasks.

There are also entrepreneurial activities that can be done very easily and required minimal traveling from home. They may initiate a beauty parlor where they provide beautician services to their female customers. Educated ladies can opt for starting a coaching/tuition academy where female students from the surrounding area can get a quality education at a low cost. Similarly, they may provide tailoring services to female clients. They can establish a handicraft center for the training of local females or they may prepare different crafts like sweaters, caps, cloth, sheets and handmade cloth, carpet, etc. When they have free time it could be utilized in-home business. Starting and running boutiques is an emerging market for females especially in urban areas. Those male family members who don't allow their females to go and buy from the shops owned by males can easily use the services offered by women-owned businesses. They may prepare pickles, jam, and squashes, etc., and sell to their customers in the local market.

Women can easily start making hand fans for the summer season on a commercial basis. In Gujarat-Pakistan, which is known for fan and other electric appliances, many women making fan instruments, etc. while in In Sialkot they are very experienced in the production of sports accessories. These kinds of activities can also get financial and religious support from family members which creates a social network/capital. These activities will not harm their religious and cultural norms as they are not working with other men. They can maintain their cultural and religious values and on the other hand, can get some money which can be used to educate and feed their kids and other family members. This money can also be used to fulfill their own financial needs and make them financially empowered.

Furthermore, the other advantage of financial independence and participation in decision making can also be attained to balance family ties. These individual businesses can also be converted into partnerships in the future. The men can bring raw materials and women can process these materials into finished goods which can be further offered by males in the markets for sale. They can offer their services in the form of dairy products, grocery shops, cloth merchants, hand embroidery products, tailoring, writing, etc.

\section{Conclusion and Future Research Direction}

Women entrepreneurs can play a crucial role to maintain and promote social and economic development in the rural and urban areas of the countries. The way forward for the encouragement of women entrepreneurship in the Islamic context needs a conducive political, economic, and educational environment (Wahid et al., 2020). More women entrepreneurial schemes should be launched where women trainers can train these women entrepreneurs in a socio-cultural and religious context to enhance their knowledge and skills. Interest-free financing schemes are the need of the day and the governments need to improve the regulatory environment to protect private-sector employment. Policies should be framed to provide tax incentives and subsidies to make it more attractive for women 
Review of Economics and Development Studies, Vol. 6 (4) 2020, 857 - 866

entrepreneurs. For sustainable growth, the government should design to direct these women entrepreneurs towards the high technology sector. This attempt was made to explore the research gap and highlight new avenues based on available literature. The need and motives of male and female entrepreneurs can be different and especially in the Islamic society which could be a gap to be explored in the future.

\section{References:}

Aidis, R., Welter, F., Smallbone, D., \& Isakova, N. (2007). Female entrepreneurship in transition economies: the case of Lithuania and Ukraine. Feminist Economics, 13(2), 157-183.

Anggadwita, G., Mulyaningsih, H., Ramadani, V., \& Arwiyah, Y. (2015). Women Entrepreneurship in Islamic Perspective: Driver for Social Change. International Journal of Business and Globalisation, 15. doi:10.1504/IJBG.2015.071914

Anna, A. L., Chandler, G. N., Jansen, E., \& Mero, N. P. (2000). Women business owners in traditional and non-traditional industries. Journal of business venturing, 15(3), 279-303.

Aparicio, S., Urbano, D., \& Audretsch, D. (2016). Institutional factors, opportunity entrepreneurship and economic growth: Panel data evidence. Technological forecasting and social change, 102, 45-61.

Baughn, C. C., Chua, B. L., \& Neupert, K. E. (2006). The normative context for women's participation in entrepreneruship: A multicountry study. Entrepreneurship Theory and Practice, 30(5), 687-708.

Baumgartner, D., Pütz, M., \& Seidl, I. (2013). What kind of entrepreneurship drives regional development in European non-core regions? A literature review on empirical entrepreneurship research. European Planning Studies, 21(8), 1095-1127.

Benería, L., \& Roldan, M. (1987). The crossroads of class and gender: Industrial homework, subcontracting, and household dynamics in Mexico City: University of Chicago Press.

Block, J. H., \& Wagner, M. (2010). Necessity and opportunity entrepreneurs in Germany: characteristics and earning s differentials. Schmalenbach Business Review, 62(2), 154-174.

Calton, J. M., Werhane, P. H., Hartman, L. P., \& Bevan, D. (2013). Building partnerships to create social and economic value at the base of the global development pyramid. Journal of Business Ethics, 117(4), 721-733.

Carter, S., Anderson, S., \& Shaw, E. (2001). Women's Business Ownership: A Review of the Academic. Popular and Internet Literature', Report to Small Business Service, SBS, Sheffield.

Chinomona, E., \& Maziriri, E. T. (2015). Women in action: Challenges facing women entrepreneurs in the Gauteng Province of South Africa. International Business \& Economics Research Journal (IBER), 14(6), 835-850.

Cosh, A. D., Hughes, A., \& Research, C. C. f. B. (2000). British enterprise in transition: Growth, innovation and public policy in the small and medium sized enterprise sector 1994-1999: ESRC Centre for Business Research Trumptington Street, University of ....

De Clercq, D., \& Honig, B. (2011). Entrepreneurship as an integrating mechanism for disadvantaged persons. Entrepreneurship \& Regional Development, 23(5-6), 353-372.

De Vita, L., Mari, M., \& Poggesi, S. (2014). Women entrepreneurs in and from developing countries: Evidences from the literature. European Management Journal, 32(3), 451-46o. doi:https://doi.org/10.1016/j.emj.2013.07.009

Eijdenberg, E. L., Paas, L. J., \& Masurel, E. (2015). Entrepreneurial motivation and small business growth in Rwanda. Journal of Entrepreneurship in Emerging Economies.

Fairlie, R. W. (2013). Entrepreneurship, economic conditions, and the great recession. Journal of Economics \& Management Strategy, 22(2), 207-231. 
Review of Economics and Development Studies, Vol. 6 (4) 2020, 857 - 866

Field, E., Pande, R., Papp, J., \& Rigol, N. (2013). Does the classic microfinance model discourage entrepreneurship among the poor? Experimental evidence from India. American Economic Review, 103(6), 2196-2226.

Fischer, G. (2013). Contract Structure, Risk-Sharing, and Investment Choice. Econometrica, 81(3), 883-939.

González-Pernía, J. L., Guerrero, M., Jung, A., \& Pena-Legazkue. (2018). Economic recession shakeout and entrepreneurship: Evidence from Spain. BRQ Business Research Quarterly, 21(3), 153-167.

Greene, P. G., Hart, M. M., Gatewood, E. J., Brush, C. G., \& Carter, N. M. (2003). Women entrepreneurs: Moving front and center: An overview of research and theory. Coleman White Paper Series, 3(1), 1-47.

Hashmi, H. S. (2018). Women Entrepreneurship in Islamic Perspective. INTERNATIONAL JOURNAL OF ISLAMIC ECONOMICS AND GOVERNANCE, 1.

Henry, C., Foss, L., \& Ahl, H. (2016). Gender and entrepreneurship research: A review of methodological approaches. International Small Business Journal, 34(3), 217-241.

Hilson, G., Hilson, A., \& Maconachie, R. (2018). Opportunity or necessity? Conceptualizing entrepreneurship at African small-scale mines. Technological forecasting and social change, 131, 286-302.

Jahanshahi, A. A., Pitamber, B., \& Nawaser, K. (2010). Issues and challenges for women entrepreneurs in global scene, with special reference to India. Australian Journal of Basic and Applied Sciences, 4(9), 4347-4356.

Jamali, D. (2009). Constraints and opportunities facing women entrepreneurs in developing countries: A relational perspective. Gender in Management: An International Journal, 24(4), 232-251.

Jennings, J. E., \& Brush, C. G. (2013). Research on Women Entrepreneurs: Challenges to (and from) the Broader Entrepreneurship Literature? The Academy of Management Annals, 7(1), 663-715. doi:10.1080/19416520.2013.782190

Jensen, K. W., Liu, Y., \& Schøtt, T. (2017). Entrepreneurs innovation bringing job satisfaction, work-family balance, and life satisfaction: In China and around the world. International Journal of Innovation Studies, 1(4), 193-206. doi:https://doi.org/10.1016/j.ijis.2017.11.002

Jones Christensen, L., Siemsen, E., \& Balasubramanian, S. (2015). Consumer behavior change at the base of the pyramid: Bridging the gap between for-profit and social responsibility strategies. Strategic Management Journal, 36(2), 307-317.

Kantor, P. (2005). Determinants of Women's Microenterprise success in Ahmedabad, India: Empowerment and Economics. Feminist Economics, 11(3), 63-83. doi:10.1080/13545700500301163

Kelley, D., Bosma, N., \& Amorós, J. E. (2011). Global entrepreneurship monitor 2010 executive report.

Kelley, D. J., et al. (2017). Women's entrepreneurship 2016/2017 report. 9(19), 2017.

Khalid, A., Hassan, S. S., Hassan, S. M., \& Adnan, M. (2020). Gender Responsive and Child Sensitive Disaster Management in Pakistan. Review of Economics and Development Studies, 6(3), 727-738. doi:10.47067/reads.v6i3.262

Kim, J. L. S., \& Ling, C. S. J. W. i. M. r. (2001). Work-family conflict of women entrepreneurs in Singapore.

Kimbu, A. N., \& Ngoasong, M. Z. (2016). Women as vectors of social entrepreneurship. Annals of Tourism Research, 6o, 63-79.

Lee Siew Kim, J., \& Seow Ling, C. (2001). Work-family conflict of women entrepreneurs in Singapore. Women in Management Review, 16(5), 204-221. 


\section{Review of Economics and Development Studies, Vol. 6 (4) 2020, 857 - 866}

doi:10.1108/o9649420110395692

Leung, Y. K., Mukerjee, J., \& Thurik, R. (2020). The role of family support in work-family balance and subjective well-being of SME owners. Journal of small business management, 58(1), 130-163.

Mair, J., Wolf, M., \& Seelos, C. (2016). Scaffolding: A process of transforming patterns of inequality in small-scale societies. Academy of Management Journal, 59(6), 2021-2044.

Marlow, S., Hart, M., Levie, J., \& Shamsul, M. K. (2012). Women in enterprise: a different perspective.

McMullen, J. S., Bagby, D. R., \& Palich, L. E. (2008). Economic freedom and the motivation to engage in entrepreneurial action. Entrepreneurship Theory and Practice, 32(5), 875-895.

Mencher, J. J. A. h. d. W., \& World, i. i. t. T. (1988). Women's work and poverty: Women's contribution to household maintenance in South India. 99-119.

Nasir, M., Iqbal, R., \& Akhtar, C. (2019). Factors Affecting Growth of Women Entrepreneurs in Pakistan. Pakistan Administrative Review, 3(1), 35-50.

Oukil, M.-S. (2013). Entrepreneurship and entrepreneurs in an Islamic context. Journal of Islamic and Human Advanced Research, 3(3), 111-131.

Özsungur, F. (2019). A research on women's entrepreneurship motivation: Sample of Adana Province. Women's Studies International Forum, 74, 114-126. doi:https://doi.org/10.1016/j.wsif.2019.03.006

Parker, S. C. (2018). The economics of entrepreneurship: Cambridge University Press.

Quran 2:275.

Rey-Martí, A., Porcar, A. T., \& Mas-Tur, A. (2015). Linking female entrepreneurs' motivation to business survival. Journal of Business Research, 68(4), 810-814.

Ribeiro, A., Rezaei, S., Dana, L.-P. J. I. J. o. B., \& Globalisation. (2012). Gender and family in transnational entrepreneurship. 8(3), 409-420.

Roomi, M. A., \& Parrott, G. (2008). Barriers to development and progression of women entrepreneurs in Pakistan. The Journal of Entrepreneurship, 17(1), 59-72.

Roomi, M. A., Rehman, S., \& Henry, C. (2018). Exploring the normative context for women's entrepreneurship in Pakistan: a critical analysis. International Journal of Gender and Entrepreneurship.

Rosa, P., \& Dawson, A. (2006). Gender and the commercialization of university science: academic founders of spinout companies. Entrepreneurship and Regional Development, 18(4), 341366.

Sadeghi, V. J., Nkongolo-Bakenda, J.-M., Anderson, R. B., \& Dana, L.-P. (2019). An institutionbased view of international entrepreneurship: A comparison of context-based and universal determinants in developing and economically advanced countries. International Business Review, 28(6), 101588.

Salman, A., \& Nawaz, H. (2018). Islamic financial system and conventional banking: A comparison. Arab Economic and Business Journal, 13(2), 155-167. doi:https://doi.org/10.1016/j.aebj.2018.09.003

Schultz, T. P. J. J. o. h. r. (1993). Investments in the schooling and health of women and men: quantities and returns. 694-734.

Shaw, E., Carter, S. L., \& Brierton, J. (2001). Unequal entrepreneurs: Why female enterprise is an uphill business.

Shinkafi Akilu, A., \& Ali Nor, A. (2018). Entrepreneurship Development in Islamic Economics. In R. Asmak Ab (Ed.), New Developments in Islamic Economics (pp. 3-18): Emerald Publishing Limited.

Shmailan, A. (2014). Female entrepreneurs in Saudi Arabia: A comparison of barriers and 
Review of Economics and Development Studies, Vol. 6 (4) 2020, 857 - 866

motivations: Moving from disenfranchisement to empowerment. Elite Research Journal of Education and Review, 2(2), 6-21.

Sun, X., Xu, H., Köseoglu, M. A., \& Okumus, F. (2020). How do lifestyle hospitality and tourism entrepreneurs manage their work-life balance? International Journal of Hospitality Management, 85, 102359. doi:https://doi.org/10.1016/j.ijhm.2019.102359

Sutter, C., Bruton, G. D., \& Chen, J. (2019). Entrepreneurship as a solution to extreme poverty: A review and future research directions. Journal of business venturing, 34(1), 197-214. doi:https://doi.org/10.1016/j.jbusvent.2018.06.003

Vladasel, T., Lindquist, M. J., Sol, J., \& van Praag, M. (2020). On the origins of entrepreneurship: Evidence from sibling correlations. Journal of business venturing, 106017. doi:https://doi.org/10.1016/j.jbusvent.2020.106017

Wahid, F. e., Jaffri, M., Ullah, H., \& Mohmand, M. I. K. (2020). Economic Empowerment of Women in Socio-Cultural Perspectives in Federally Administrative Tribal Area (Pakistan): A Case Study of Kurram Agency. Review of Economics and Development Studies, 6(2), 257-266. doi:10.47067/reads.v6i2.201

Watson, J., \& Robinson, S. (2003). Adjusting for risk in comparing the performances of male-and female-controlled SMEs. Journal of business venturing, 18(6), 773-788.

Williams, C. C. (2008). Beyond necessity-driven versus opportunity-driven entrepreneurship: a study of informal entrepreneurs in England, Russia and Ukraine. The International Journal of Entrepreneurship and Innovation, 9(3), 157-165.

Williams, N., \& Williams, C. C. (2014). Beyond necessity versus opportunity entrepreneurship: some lessons from English deprived urban neighbourhoods. International Entrepreneurship and Management Journal, 10(1), 23-40.

Zafar, M. B., \& Sulaiman, A. A. (2020). Islamic Banking in Pakistan: Emergence, Growth, and Prospects. In Growth and Emerging Prospects of International Islamic Banking (pp. 61-77): IGI Global.

Zeb, A., \& Ihsan, A. (2020). Innovation and the entrepreneurial performance in women-owned small and medium-sized enterprises in Pakistan. Women's Studies International Forum, 79, 102342. doi:https://doi.org/10.1016/j.wsif.2020.102342 